\title{
SCIENCEConf
}

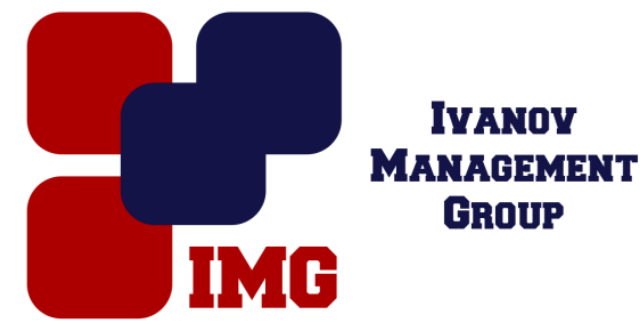

\author{
Старожилов В.Т. \\ Дальневосточный федеральный университет \\ Владивосток, Россия
}

doi: $10.18411 / \mathrm{spc}-31-05-2017-10$

idsp 000001:spc-31-05-2017-10

\section{Концепция классификации видов индикаци ландшафтных геосистем}

В работе впервые для Тихоокеанской России рассматривается классификация видов индикации ландшафтных геосистем на основе результатов научных и практических исследований в сфере геолого-географического изучения и ландшафтного картографирования крупных региональных Приморского, Сахалинского и др. звеньев окраинно-континентального ландшафтного пояса Тихоокеанской России [5]. Они тематически продолжают ландшафтные исследования России и региональных её звеньев, a среднемасштабное слоевое картографирование с использованием региональной типологической классификации позволило отразить особенности геосистем, проявляющие в различных частях их ареалов, а описание выявило свойства и степень различия между ландшафтными геосистемами. Это подготовило основу для применения метода индикации и по объектной классификации видов индикации.

В основу классификации положены результаты 30 летних полевых исследований и научного изучения соотношения и взаимосвязи достаточно значимых выборок данных не только по рельефу, растительности и почвам, но и коренным и рыхлым породам, климату и другим компонентам внутреннего содержания ландшафтных геосистем [6]. По отдельным регионам, изучаемого Тихоокеанского ландшафтного пояса России, материал картографирован с учетом окраинно-континентальной дихотомии и данных по орографическому, климатическому и фиторастительному факторам географически единых 
территорий в рамках горной ландшафтной географии. Учитывались материалы ландшафтных карт СССР масштабов 1: 2500000 [2] и 1: 4000000 [3], ландшафтные карты Приморского края в масштабе 1: 1000000 [7] и Сахалинской области в масштабе 1: 2000000 [4], и др.

На примере Приморского края и Сахалинской области в масштабе 1:500 000 выделены и картографированы классы, подклассы, роды, виды ландшафтов и местности (индивидуальные ландшафты). Далее материал уже на базе выделенных таксонов снова проанализирован и были выделены и закартографированы округа, провинции и области. В частности только по Приморскому краю выделено 54 округа [9] и 3156 выделов индивидуальных ландшафтов [7,8]

Представленные ландшафтные основы в свою очередь это основа для практической реализации ландшафтного подхода в различных областях науки и практики при освоении Тихоокеанской России, в частности в экологии, охране окружающей среды и в целом природопользовании [10]. Одним из главных методов при практической реализации ландшафтного подхода нами применяется метод ландшафтной индикации $[6,11,12]$. Он включает исследование индикаторов и индикационных связей, отражающих объекты индикации, обусловленных антропогенной трансформацией, разработкой мер по охране природной среды. Нами проведена на практике индикация в области промышленного освоения, индикация денудации, химических и механических изменений компонентов ландшафтов и других процессов и объектов [10]. В свою очередь весь полученный материал по индикации был синтезирован, проанализирован и структурно классифицирован. Ниже приводятся общая концепция классификации видов индикации геосистем, которая включает:

1. Представление ландшафтной основы индикации;

2. Организационные уровни индикации ландшафтных геосистем;

3. Общая компонентная индикация;

4. Морфологическая структурная индикация;

5. Компонентная площадная индикация:

6. Комплексная площадная индикация;

1. Представление ландшафтной основы индикации. Практика индикации горно-промышленных производств, эрозионно-денудационных систем, химических, механических изменений компонентов ландшафтов и других 
процессов и систем показывает, что для индикации ландшафтных геосистем прежде всего необходимо иметь морфологическую модель ландшафтов. Пример такой модели - морфологическая модель Приморского края, представленная местностями, видами, родами, подклассами, классами, округами, провинциями и областями ландшафтов. В целом полученная организованная система является базовой моделью, которая представляет основу для индикации и для решения прикладных задач. Установлено, что в целом для оптимально значимой индикации необходимо знание прежде всего морфологии географического пространства, отображенной в границах на морфологической карте ландшафтов исследуемой территории.

2. Организаџионные уровни индикаџии ландиафтных геосистем. Строение ландшафта выражается в наличии системы пространственно взаимосвязанных и соподчиненных ПТК. А.К. Исаченко выделяет три уровня строения ландшафтов - локальный, региональный и глобальный. Каждый уровень, выбираемый в зависимости от масштаба исследования, представлен различными ПТК. Наиболее важными, разработанными и широко используемыми в практике являются единицы ПТК локального и регионального уровня. В практике наших исследований индицируются эти же единицы организации ландшафтов и компоненты их внутреннего содержания, а полученные результаты их индикации используются при решении комплексных природопользовательских и экологических задач. Практика индикации внутреннего содержания единиц ландшафтов на примере ландшафтных геосистем Приморского края и на примере горно-промышленного комплекса [6] показала, что индикации подвергались урочища, индивидуальные ландшафты, виды, роды, подклассы, классы, округа, провинции и области. Они организованы в два организационных уровня индикации: локальный (урочища) и региональный (все классификационные единицы ландшафтов - виды, роды, подклассы, классы и др.). Опираясь на практику индикации и следуя принципам ландшафтных классификаций выделяется в классификации индикации три организационные уровня индикации ландшафтных геосистем: локальный, региональный, планетарный.

3. Общзая компонентная индикац̧ия. Под компонентным индикатором ландшафта понимается те его параметры, механизмы функционирования, которые могут способствовать или не способствовать проявлению экологических проблем, или которые имеют важное значение для жизнедеятельности человека. Они проявляются при сведении растительности, уничтожении природных почв, 
изменениях рельефа, загрязнении компонентов и т.д.). Для получения данных по площадям и свойствам природных ландшафтов региона необходимо иметь оцифрованную ландшафтную карту.

4. Морфологическая структурная индикация. В процессе ландшафтных исследований территории наряду с локальными индикаторами - почвами, растительностью, рельефа, геологии, климата - важное значение имеет и интегральный - специфика морфологической структуры, которая показывает взаимосвязь элементов и компонентов ландшафтов, Морфологическая структура, сформировавшаяся при сложном взаимодействии эндогенных и экзогенных факторов, является объективным отражением сложных процессов вещественноэнергетического обмена между компонентами, поэтому анализ ее пространственной упорядоченности в системах любого ранга выступает как важный индицирующий природный процесс признак. Суть метода ландшафтной индикации в его приложении к познанию взаимосвязанных объектов природы, хозяйства заключается прежде всего в распространении знания о части объекта, или его структурного элемента на весь объект природопользования.[1,6]

5. Компонентная площадная индикащия; При анализе ландшафтного подхода для целей изучения степени трансформации ландшафтов по индикаторным компонентам степень индикации нами изучена по соотношению площадей индикаторов природных и модифицированных систем. Определялись соотношения площадей почвенных, рельефных, геохимических и др. индикаторных компонентов, они обозначены коэффициентами.

Выделяется ряд коэффициентов: К1, К2, К3 и т. д.

К1, К2, К3, Кn - коэффициенты соотношений площадей ландшафтных природных (эталонных) и техногенных индикаторных компонентов ландшафтов (почвенных, растительных, геохимических и т. д.). Подсчет коэффициентов производился по формуле: $\mathrm{K}=\mathrm{S}$ / S 1, где:

K - коэффициент соотношения площадей соответствующего компонентного индикатора ландшафта;

$\mathrm{S}$ - площадь природного (эталонного) ландшафта;

$\mathrm{S} 1$ - площадь модифицированного соответствующего компонентного индикатора ландшафта;

На основе полученных материалов сделан вывод, что индикационные составляющие любых анализируемых систем распространены на определенной площади и учет соотношения площадей природных и модифицированных 
ландшафтов при анализе трансформации территорий показателен в отношении определения степени их модификации.

6. Комплексная площадная индикация; Процесс модификации и трансформации, происходит в ландшафтах с определенной площадью. Обозначим площадь природного (эталонного) ландшафта $\mathrm{S}$, a площадь модифицированного S 1, затем разделим площади друг на друга и получим отношение, характеризующее площадное изменение ландшафтных свойств (C). То есть, получена формула С = S / S 1 где:

$\mathrm{S}$ - площадь природного (эталонного) ландшафта;

S 1 - площадь модифицированного ландшафта;

C - коэффициент площадного изменения соответствующей таксономической единицы ландшафта;

Эти несложные арифметические действия дают возможность по коэффициенту рассчитывать изменения выделов ландшафтов, сравнивать их между собой, решать вопросы связанные с модификацией структуры и организации ландшафтов.

Итак для Тихоокеанской России, на примере Тихоокеанского ландшафтного пояса разработана концепция классификации видов индикации. Она поможет в освоении, осуществлении экологически чистого природопользования и сбалансированного развития Тихоокеанской России 
1. Булатов В.И. Антропогенная трансформация ландшафтов и решение региональных проблем природопользования (на примере юга Западной Сибири). Дисс.на соиск. Уч. степ. Доктора географ. Наук в форме науч. докл. - Иркутск, 1996. - 63 с.

2. Ландшафтная карта СССР масштаба 1: 2500 000. / Мин-во геологии СССР. / Отв. ред. И.С. Гудилин. - М.: Гидроспецгеология., 1980. 12 листов.

3. Ландшафтная карта СССР. Масштаб 1: 4000000 / науч. редактор Исаченко А.Г. М.: ГУГК, 1985. 2 листа.

4. Нефедов В.В. Ландшафтная карта Сахалинской области масштаба 1: 2000 000. Атлас Сахалинской области.- М., 1967.

5. Старожилов В.Т. Тихоокеанский окраинно-континентальный ландшафтный пояс как географическая единица Тихоокеанской России и вопросы практики // Проблемы региональной экологии. 2013. №5. С. $1-7$.

6. Старожилов В.Т. Ландшафтная география Приморья (регионально-компонент-ная специфика и пространственный анализ геосистем). Владивосток: Изд-во Дальневост. федер. ун-та, 2013а. Часть 1.276 с.

7. Старожилов В.Т. Карта ландшафтов Приморского края. Масштаб 1: 1000000. Владивосток: Изд-во Дальнев. ун-та. 2009.1 лист.

8. Старожилов В.Т. Ландшафты Приморского края (Объяснительная записка к карте масштаба 1: 500 000). - Владивосток: Изд-во Дальнев. ун-та. 2009а. - 368 с.

9. Старожилов В.Т. Ландшафтная география Приморья. (районирование). - Владивосток: Изд-кий дом Дальнев. федер. ун-та, 2013б. Кн. 2. - 272 с.

10. Старожилов В.Т. Ландшафтная география Приморья (практика). Владивосток: Изд-ский дом Дальнев. федер. ун-та, 2013в. Кн. 3. 276 с.

11. Старожилов В.Т Ландшафтная индикация трансформации геосистем // Структурные трансформации в геосистемах Северо-Восточной Азии : материалы Всерос. науч.-практ. конф. 23-24 апр. 2015. - Владивосток : Дальнаука 2015. - С. 86-91.

12. Старожилов В.Т Концепция ландшафтной индикации в политике Тихоокеанского международного ландшафтного центра ШЕН ДВФУ // Сб. науч. статей по итогам междун. науч.-практ. конф. «Современный взгляд на будущее науки: приоритетные направления и инструменты развития». Санкт-Петербург. 2017. С 35-37 . 